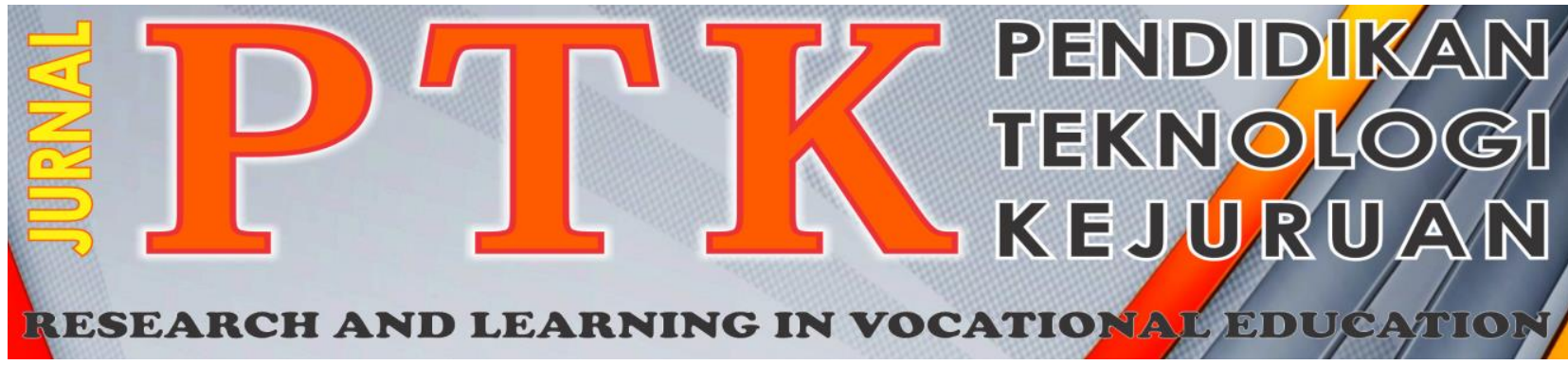

Vol. 2, No. 4, 2019

P-ISSN: 2621-3273

E-ISSN: 2621-1548

\title{
Analisis Aliran Air Bawah Permukaan Dengan Menggunakan Metode Geolistrik
}

\author{
Muhamad Ragil Setiawan ${ }^{1 *}$, Bilal Al Farishi ${ }^{2}$, Lea Kristi Agustin ${ }^{3}$ \\ ${ }^{1}$ Program Studi Fisika, Jurusan Sains, Institut Teknologi Sumatera \\ ${ }^{2}$ Program Studi Teknik Geologi, Jurusan Teknologi Produksi dan Industri, Institut Teknologi Sumatera \\ ${ }^{3}$ Program Studi Teknik Geomatika, Jurusan Teknologi Infrastruktur dan Kewilayahan, Institut Teknologi \\ Sumatera \\ *Corresponding author, e-mail: ragil.setiawan@fi.itera.ac.id ${ }^{1}$
}

\begin{abstract}
Abstrak- Air bersih merupakan kebutuhan manusia dalam suatu komunitas. Kebutuhan air bersih dapat diambil dari air bawah permukaan melalui proses pemompaan. Upaya mendapatkan air bersih yang memiliki keberlanjutan baik dapat dilakukan dengan mengetahui arah aliran akuifer. Arah aliran akuifer dapat diketahui melalui pemodelan bawah permukaan. Penelitian ini menggunakan metode geolistrik dalam memodelkan lapisan di bawah permukaan guna mengetahui posisi akuifer. Berdasarkan model bawah permukaan, kedalaman rata-rata akuifer antara 30-100 meter. Model lapisan bawah permukaan menunjukkan jenis akuifer tertekan dengan lapisan lempung sebagai batas atas dan bawah akuifer. Air bawah permukaan diperkirakan memiliki arah aliran dari Timur ke Barat pada akuifer tertekan.
\end{abstract}

Kata kunci: Air bersih, geolistrik, aliran akuifer

Abstract- Cean water is needed in a human community. The need for clean water can be taken from subsurface water through a pumping process. Efforts to get clean water that has sustainability can be done by knowing the direction of the aquifer flow. The direction of the aquifer flow can be known through subsurface modeling. This study uses the geoelectric method in modeling the subsurface layer to determine the position of the aquifer. Based on the subsurface model, the average depth of an aquifer is between 30-100 meters. The subsurface model shows the type of aquifer depressed with a clay layer as the upper and lower limits of the aquifer. The subsurface water is estimated to have a flow direction from East to West in a confined aquifer.

Keywords: clean water, geoelctric, aquifer flow

\section{Pendahuluan}

ITERA merupkan perguruan tinggi negeri yang terletak di Provinsi Lampung dengan luas wilayah kurang lebih 275 Ha. Sebagai perguruan tinggi negeri baru, jumlah mahasiswa saat ini sudah mencapai lebih dari 5000 orang dengan staf dosen dan tenaga kependidikan lebih dari 500 orang. Banyaknya jumlah sivitas akademika berkorelasi dengan kebutuhan air bersih di ITERA. Langkah dan upaya untuk menyediakan air bersih adalah melalui pemanfaatn potensi air bawah permukaan pada daerah tersebut. Air bersih di Kampus ITERA dan sekitarnya baik diperoleh dari akuifer tertekan dibandingkan dari akuifer tidak tertekan [1].

Kondisi geologi ITERA berada pada formasi Lampung yang tersusun atas tufa, batuan lempung tufan dan batu pasir tufan[2]. Kondisi lapisan permukaan yang tersusun atas tufan mencirikan aliran akuifer dengan poduktifitas rendah karena ukuran butir kecil.

Eksplorasi air bawah permukaan dapat dilakukan dengan berbagai metode, salah satu metode yang paling banyak digunakan adalah metode geolistrik. Penggunaan metode geolistrik dalam pendugaan kondisi akuifer dilakukan sebagai alternatif dalam menemukan zona akumulasi akuifer. Metode geolistrik digunakan dalam melakukan pendugaan akuifer karena dapat membedakan sifat kelistrikan perlapisan batuan di bawah permukaan. Metode ini memiliki keunggulan dalam eksplorasi dangkal karena tidak bersifat merusak. Pendeteksian kondisi bawah permukaan dengan menginjeksikan arus listrik ke tanah dan mengukur medan potensial yang 
merupakan hasil interaksi antara arus listrik dengan lapisan bawah permukaan. Keberadaan air yang memiliki sifat konduktiftas tinggi akan dapat terdetekasi dengan melihat nilai resistivitas yang dihitung dari harisl pengukuran yang dilakukan. Pengukuran dengan metode geolistrik ini betujuan untuk menentukan posisi akuifer dan memprediksi arah aliran air bawah permukaan.

\section{StUdi Pustaka}

Batuan merupakah materi dasar penyusun bumi yang tersusun atas berbagai jenis mineral, gabungan minel, bahan-bahan organik serta bahan-bahan vulkanik. Masing-masing penyusun tersebut memiliki sifat kelistrikan yang berbeda-beda. Hal ini berkaitan dengan kemampuan material tersebut dalam menghantarkan arus listrik. Aliran arus listrik di dalam batuan dan ineral dapat digolongkan menjadi tiga macam, yaitu konduksi secara elektronik, konduksi secara elektrolitik, dan konduksi secara dielektrik [3].

Salah satu metode yang dapat digunakan untuk mengidentifikasi sifat kelistrikan batuan adalah metode geolistrik resistivitas. Prinsip metode ini adalah penginjeksian arus listrik ke bawah permukaan melalui suatu penghantar (elektroda arus, A dan B) dan mengukur respon beda potensial melalui elektroda potensial $\mathrm{M}$ dan $\mathrm{N}$ (Gambar 1). Sehingga metode ini sering disebut metode geolistrik aktif. Beda potensial yang terukur di permukaan akan berbeda-beda yang menunjukkan ketidaksamaan nilai konduktivitas batuan dalam menghantarkan arus listrik. Nilai konduktivitas memiliki hubungan terbalik dengan hambatan jenis suatu penghantar. Hubungan antara arus listrik (I) dan beda potensial $(V)$ dengan hambatan jenis diberikan oleh hukum Ohm,

Kerena,

$$
\delta V=I \delta R
$$

$$
\begin{aligned}
& \delta R=\frac{\rho \delta L}{\delta A}, \text { maka } \\
& \rho=\frac{\delta V \delta A}{I \delta L}
\end{aligned}
$$

Metode geolistrik Vertical Electrical Sounding (VES) merupakan salah satu metode geolistrik yang mampu membedakan perubahan resistivitas di bawah permukaan kearah vertikal. Konfigurasi elektroda yang biasa digunakan dalam survei VES adalah konfigurasi Schlumberger. Konfigurasi ini menggunakan jarak antara elektroda yang tidak seragam. Jarak antara dua elektroda potensial lebih dekat dibandingkan dengan jarak antara elektroda arus dan potensial. Konfigurasi ini dapat dilihat pada Gambar 1.

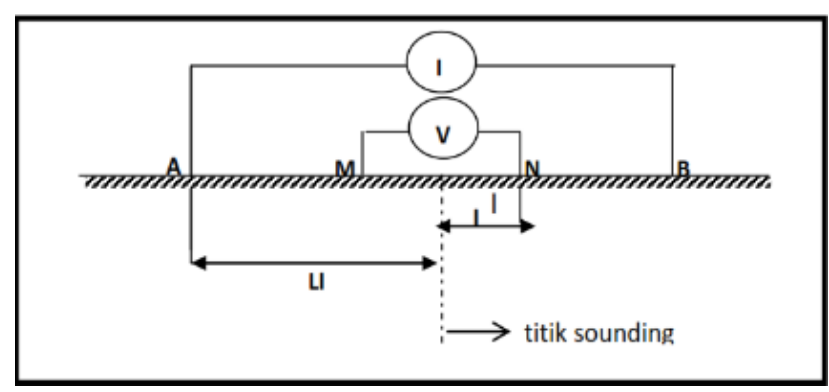

Gambar 1. Konfigurasi Schlumberger yang memperlihatkan jarak antar elektroda yang tidak seragam [4].

\section{METODE}

Lokasi penelitian dilakukan di area pendirian Institut Teknologi Sumatera yang berada di antara $105,30^{\circ} \mathrm{BT}-105,31^{\circ} \mathrm{BT}$ dan $5,35^{\circ} \mathrm{LS}-5,37^{\circ} \mathrm{LS}$. Penelitian dilakukan dengan menggunakan metode resistivitas geolistrik VES dengan konfigurasi Schlumberger. Pemilihan konfigurasi ini dilakukan karena dapat mendeteksi terobosan serta jangkauan yang dalam. Metode ini memiliki faktor geometri $k$ sebesar,

$$
k=\frac{\pi\left(u^{2}-l^{2}\right)}{2 l}
$$

Dimana $u$ adalah jarak satu elektroda arus ke titik sounding, dan $l$ adalah jarak antara satu elektroda potensial ke titik sounding [2]. Data yang diperoleh pada saat pengukuran adalah data arus listrik dan beda potensial antara elektroda $\mathrm{M}$ dan N. Data tersebut dicatat pada logbook pengukuran.

Peralatan yang digunakan dalam pengambilan data geolistrik antara lain: Seperangkat alat Geolistrik iRES T300F; Handy Talky; GPS; kabel penghubung; accu; rol meter; kompas geologi; palu; terpal; alat tulis; payung; 4 buah elektroda; software IP2WIN. Akuisisi data geolistrik dilakukan dengan injeksi arus listrik ke dalam bawah permukaan melalui elektroda arus (A dan B). Respon yang diukur di permukaan adalah nilai beda potensial yang diukur melalui elektroda $\mathrm{M}$ dan N. Panjang lintasan setiap titik pengukuran adalah 200-300 meter ke kanan dan kiri.

Pengukuran dilakukan pada beberapa titik (Gambar 1), yakni titik T12, T13, T14 dengan jarak spasi 100 meter berada di Timur laut, titik T33, T43, T51 dengan jarak antar titik 200 meter berada di sebelah Barat, titik T72, T74, dan T76 dengan spasi 200 meter berada di sebelah Selatan, serta titik T28, T29, T30 [1] dengan jarak antar titik 100 meter berada di dekat Sumur tua. 


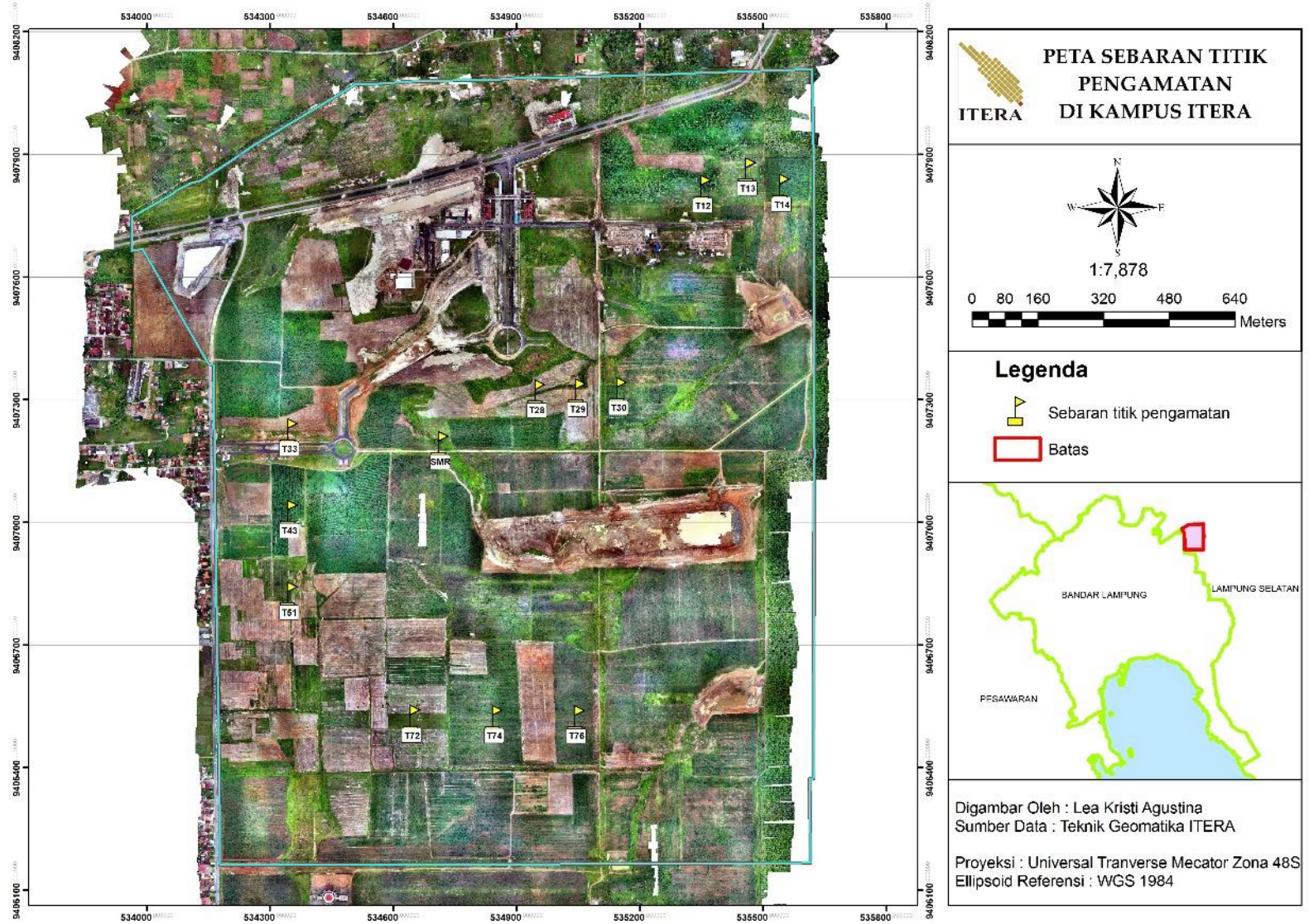

Gambar 2. Peta penelitian dengan bendera merah menunjukkan titik pengukuran VES.

\section{HASIL DAN PEMBaHASAN}

\section{A. Topografi daerah penelitian}

Topografi daerah penelitian ditunjukkan Gambar 3. Secara umum daerah penelitian merupakan kawasan yang relatif datar. Topografi daerah penelitian sebelah Barat relatif lebih tinggi dibandingkan daerah Timur. Rata-rata ketinggian permukaan di sebelah Barat (warna merah) adalah 100 meter. Sedangkan pada bagian Timur, ketinggian terendah (warna biru) adalah sekitar 78 meter. Bagian Tenggara daerah penelitian memiliki topografi rendah lebih banyak dibandingkan yang lainnya. Beda ketinggian antara kawasan yang tinggi dan yang datar berada di rentang kurang dari $50 \mathrm{~m}$, beda tinggi ini mempunyai persen lereng berkisar 3\%-7\%. Berdasarkan persen lereng tersebut, kawasan ini dikategorikan sebagai kawasan bergelombang landai [5]. Arah aliran air permukaan diperkirakan dari arah Barat ke Timur yang ditunjukkan arah anak panah pada Gambar 3.

\section{B. Kajian bawah permukaan berdasarkan data geolistrik.}

Data pengukuran geolistrik yang diperoleh dari pengukuran kemudian diolah untuk mendapatkan nilai resistivitas. Nilai resistivitas hasil perhitungan digunakan untuk menghitung nilai resistivitas semu (rho apparent). Faktor geometri berfungsi didalam perhitungan ini. Nilai resistivitas semu yang diperoleh kemudian diolah dengan menggunakan bantuan software IP2win dengan tambahan masukan data spasi elektroda.

Proses yang dilakukan di dalam software adalah pemodelan kedepan (forward modeling) dan pemodelan kebelakang (inverse modeling). Pada pemodelan kedepan, dilakukan pencocokan antara kurva teoritis dengan kurva hasil pengukuran. Metode pencocokan ini disebut dengan curve matching. Setelah diperoleh fitting kurva dengan error terkecil, maka dilakukan pemodelan kebelakang. Hal ini digunakan untuk memperoleh nilai hambatan jenis batuan dari perlapisan batuan. Selain itu, dari pemodelan ini diperoleh juga kedalaman dan ketebalan dari lapisan. 


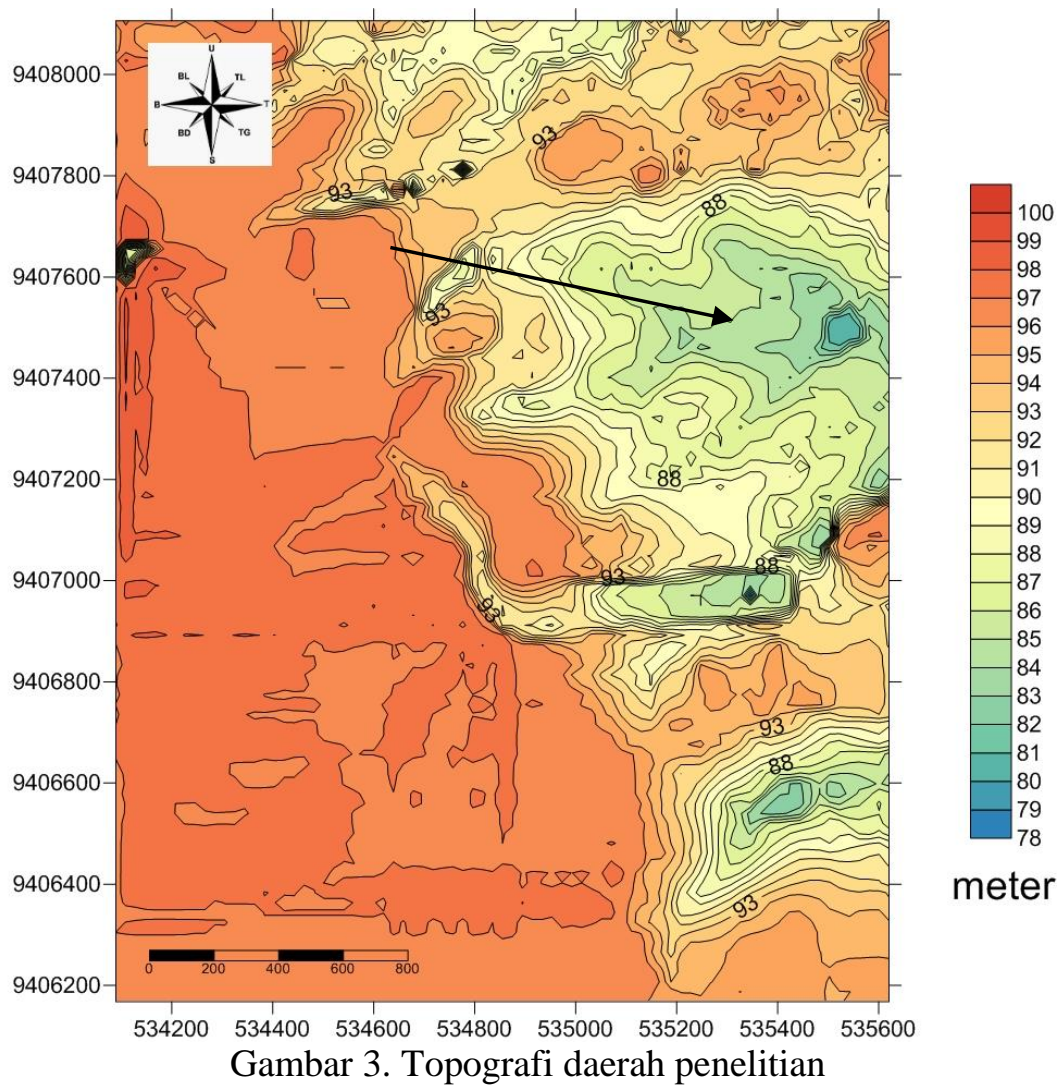

Berdasarkan hasil pemrosesan data dari 15 titik sounding (VES) yang telah dilakukan, secara umum daerah penelitian terdiri dari 4 jenis lapisan yang masing-masing dibedakan berdasarkan nilai tahanan jenis yang dimilikinya. Dari kedalaman 0-1.4 m dari permukaan didapati lapisan Tuff dengan nilai tahanan jenis berkisar 200-1000 Wm. Perbedaan nilai tahanan jenis yang cukup besar ini disebabkan oleh perbedaan kandungan air/kelembaban batuan di setiap tempat berbeda-beda, akan tetapi batuan ini dapat dipastikan sebagai Tuff berdasarkan buktibukti yang dapat dilihat langsung di permukaan daerah penelitian. Batuan ini juga menjadi litologi utama di seluruh permukaan daerah penelitian. Tuff di kawasan ini memiliki ciri berwarna putih, ukuran butir nya beragam dari halus-sedang. Dan dibeberapa tempat dapat dilihat bahwa batuan ini diendapkan di media air yang ditunjukkan dari hadirnya struktur-struktur sedimen di batuan piroklastik ini.

Lapisan selanjutnya yang dapat dilihat berdasarkan data yang telah diproses adalah Batu Lempung Pasiran. Terminologi Lempung Pasiran yang digunakan bukanlah merujuk secara pasti tentang jenis batuannya (batuan sedimen), akan tetapi lebih kepada ukuran butir nya. Hal ini karena lapisan ini masih berpotensi bersumber dari letusan gunung api, sehingga masih digolongkan menjadi batuan piroklastik atau vulkanoklastik. Lapisan ini mempunyai nilai tahanan jenis berkisar 13,9-174 $\Omega \mathrm{m}$. Ketebalan lapisan ini berkisar antara 1,6 m hingga 7,2 $\mathrm{m}$. Lapisan lempung pasiran yang paling tebal berada di T12 yaitu berada di bagain Timur Laut dari daerah penelitian.

Lapisan selanjutnya yang dapat dijumpai adalah lapisan dengan ukurang butir yang sama yaitu lapisan Lempung pasiran. Namun perbedaannya adalah lapisan selanjutnya yang berada lebih bawah dari lapisan lempung pasiran sebelumnya diinterpretasikan sebagai lapisan akifer. Lapisan ini ditafsirkan sebagai lapisan yang berada di badan batuan yang sama dengan lapisan yang sama. Akan tetapi dari data yang diperoleh, teradapat perbedaan nilai tahanan jenis yang signifikan karena perbedaan kandungan air. Akifer yang ditemukan ini merupakan akifer tertekan (confined aquifer) atau sering juga disebut sebagai akifer dalam.

Koordinat titik pengukuran, elevasi dan letak akuifer ditunjukkan pada Tabel 1 . 
Tabel 1. Koordinat titik pengukuran dan posisi akuifer.

\begin{tabular}{cccccc}
\hline No & Nama titik & Koordinat $\mathbf{X}$ & Koordinat $\mathbf{Y}$ & Elevasi (m) & Posisi Akuifer (m) \\
\hline 1 & T28 & 534950 & 9407315 & 111 & 74.7 \\
2 & T29 & 535049 & 9407317 & 101 & 31.6 \\
3 & T30 & 535149 & 9407321 & 100 & 7.1 \\
4 & T12 & 535349 & 9407818 & 111 & 43.7 \\
5 & T13 & 535449 & 9407817 & 111 & 12.2 \\
6 & T14 & 535549 & 9407816 & 120 & 31.2 \\
8 & T33 & 534348 & 9407220 & 90 & 55.6 \\
9 & T43 & 534348 & 9407020 & 90 & 48.7 \\
10 & T51 & 534347 & 9406820 & 125 & 12.4 \\
11 & T72 & 534646 & 9406519 & 111 & 37.8 \\
12 & T74 & 534846 & 9406519 & 141 & 62.9 \\
13 & T76 & 535046 & 9406518 & 111 & 70.3 \\
\hline
\end{tabular}

Berdasarkan tabel diatas, dapat dilihat bahwa di titik T30 teridentifkasi bahwa akifer berada di kedalaman 7,1 meter dari atas permukaan. Berdasarkan observasi lapangan hal ini sebenarnya bukanlah lapisan akifer, tapi merupakan laluan air tanah melalui patahan/rekahan sehingga air tanah ini muncul sebagai mata air di titik T28 yang hanya berjarak $200 \mathrm{~m}$ dari titik T30. Arah kemiringan kekar/patahan ke arah titik T30 (ke arah Timur) menjadikan bacaan nilai T30 menjadi rendah, sehingga teridentifikasi sebagai akifer di kedalaman $7,1 \mathrm{~m}$. Berdasarkan hasil kedalaman akifer yang telah dicatat, dapat dilihat bahwa secara umum akifer berada di kedalaman yang lebih dangkal di daerah Barat \& Barat Daya, dan semakin dalam ke arah Timur \& Tenggara. Seperti halnya lempung pasiran yang dijumpai di lapisan sebelumnya, lapisan yang menjadi akifer ini juga ditafsirkan sebagai batuan piroklastik dengan ukuran lempung pasiran dan bukanlah batuan sedimen.

Lapisan selanjutnya yang ditemukan adalah lapisan batu pasir. Lapisan ini mempunyai tahanan jenis 1669-3287 $\Omega \mathrm{m}$. Nilai yang tinggi ini ditafsirkan akibat konsolidasi dari batuan ini. Konsolidasi ini bisa diakibatkan oleh pembebanan lapisan batuan yang terdapat di atasnya. Ketebalan lapisan ini tidak dapat diketahui secara pasti dikarenakan kedalaman titik sounding tidak mampu mencapai batas bawah dari lapisan ini. Batu pasir ini juga merujuk kepada ukuran butir bukan kepada jenis batuan sedimen. Walau bagaimanapun untuk memastikan jenis batuan, perlu dilakukan analisis lebih lanjut, akan tetapi di penelitian ini tidak dilakukan karena tidak menjadi ruang lingkup dari penelitian ini.

\section{KESIMPULAN}

Air tanah sebagai sumber utama air bersih di lokasi penelitian merupakan bagian penting. Aliran air di permukaan mengikuti topografi, dimana daerah Timur memiliki topografi lebih rendah dibandingkan bagian Barat. Berdasarkan hukum fisika, air akan mengalir dari arah Barat ke Timur.

Akuifer air yang diukur pada beberapa titik di daerah penelitian diperoleh kedalaman rata-rata pada 30-100 meter di bawah permukaan. Model bawah permukaan juga menunjukkan arah aliran air diduga dari arah Timur ke Barat pada akuifer tertekan.

\section{DAFTAR Pustaka}

[1] Siringoringo, L. P., Reza R., and Janner N., Hydrogeochemical and Groundwater Assessment for Drinking Purpose at ITERA Campus Area and Its Surrounding, Journal of Geoscience, Engineering, Environment, and Technology, vol. 04 No. 01, p.40-48, 2019.

[2] Setiawan, M.R., Badri, R.M., Singarimbun, A., Kajian Awal Pendugaan Akuifer Air Tanah di Kampus ITERA dengan Metode Geolistrik Konfigurasi Schlumberger, J.Sci. App. Teknol. Sumatera, vol. 2, p. 40-46, 2017.

[3] Telford, W. M., R.P. Geldart, and E. Sherrif, Applied Geophysics $2^{\text {nd }}$ Edition, Cambridge Univeristy Press, 1990.

[4] Kearey, P., Michael, B., Ian, H., An Introduction to Geophysical Exploration $3^{\text {rd }}$ Edition, Blackwell Science, 2002.

[5] Van Zuidam, R. A., Guide to Geomorphology Aerial Photographic Interpretation and Mapping, ITC, Enschede, The Netherlands, 1983. 


\section{Biodata Penulis}

Muhamad Ragil Setiawan, lahir di Rembang, 13 September 1991. Sarjana Pendidikan di Jurusan Fisika UNNES 2013. Tahun 2015 memperoleh gelar Master of Science di program studi S2-Ilmu Fisika UGM dengan bidang konsentrasi Geofisika. Staf pengajar di program studi S1-Fisika ITERA sejak tahun 2016-sekarang.

Bilal Al Farishi, dilahirkan di Sungai Pakning, 21 Agustus 1992. Menyelesaikan S1 Geologi di National University of Malaysia tahun 2014 dan pendidikan Pascasarjana (S2) Magister Geophysics pada tahun 2015. Sejak tahun 2016 menjadi staf pengajar tetap di Program Studi Teknik Geologi Jurusan Sains, Institut Teknologi Sumatera.

Lea Kristi Agustina, dilahirkan di Muara Bungo, 21 Agustus 1990. Menyelesaikan pendidika Sarjana (S1) Geodesi di Universitas Diponegoro pada tahun 2012 dan pendidikan Pascasarjana (S2) Magister Geomatika di Universitas Gadjah Mada pada tahun 2016. Sejak tahun 2017 menjadi staf pengajar tetap di Program Studi Teknik Geomatika Jurusan Teknologi Infrastruktur dan Kewilayahan, Institut Teknologi Sumatera. 